DOI: $10.17805 /$ trudy.2017.6.4

\title{
УЧЕБНАЯ ЭКСКУРСИЯ КАК СОВРЕМЕННАЯ ФОРМА ИНТЕРАКТИВНОГО ЗАНЯТИЯ
}

\author{
А. В. Воронина, М. С. Марянян \\ Московский гуманитарный университет
}

Аннотация: В статье рассмотрена реализация внеурочной деятельности в колледже Московского гуманитарного университета студентами 3 курса специальности «Туризм», разобраны современные формы интерактивного занятия на примере учебной экскурсии в виде ролевой и деловой игры в г. Коломну, описан процесс учебной экскурсии, которую подготовили студенты при помощи преподавателей, проанализирована проведенная совместная работа.

Ключевые слова: учебная экскурсия; ролевая игра; деловая игра; туризм; экскурсия;внеаудиторная деятельность; интерактивное занятие творчество; анимация; досуг; Коломна; мотивация

\section{EDUCATIONAL TRIP AS A MODERN FORM OF INTERACTIVE LESSON}

\author{
A. V. Voronina, M. S. Maryanyan \\ Moscow University for the Humanities
}

\begin{abstract}
This article deals with the implementation of extracurricular activity of the third-year students majoring in Tourism at the College of Moscow University for the Humanities. It develops the modern forms of interactive lesson exemplified by the educational trip to Kolomna in the form of role playing and business game. It describes the process of the educational trip, which was prepared by the students and teachers. It analyses the co-operative work involved.

Keywords: educational trip; role-playing game; business game; tourism; trip; extracurricular activity; interactive lesson; creativity; animation; leisure; Kolomna; motivation
\end{abstract}

В условиях реализации федерального государственного образовательного стандарта среднего профессионального стандарта в Российской Федерации целью образования является формирование у обучающихся общих и профессиональных компетенций для выполнения ими трудовых функций и действий по конкретным специальностям и профессиям.

Учебная экскурсия как современная форма интерактивного занятия, на наш взгляд, позволяет обучающимся лучше освоить междисциплинарный курс или ощутить свои пробелы в формирования профессиональных 
компетенций. Это замечательная форма объединения учебного процесса с реальной профессиональной жизнью, которая позволяет также развивать познавательные способности студентов (мышление, восприятие, наблюдательность, внимание, воображение), почувствовать, реально ощутить особенности приобретаемой профессии (Емельянов, 2007).

Внеурочная деятельность носит обязательный характер и связана с тематикой изучаемых междисциплинарных курсов. Она является частью учебно-воспитательного процесса и должна быть систематической, отличаться вариативностью, способствовать индивидуализации обучения, развитию исследовательских и творческих способностей учащихся. Современный студент не всегда правильно проводит досуг. Именно эти риски досуга и призвана преодолеть специально организуемая педагогами колледжа Московского гуманитарного университета внеурочная деятельность.

Преподаватели специальности «Туризм» рассматривают внеурочную деятельность как мотиватор, способ развития познавательного интереса к профессиональным дисциплинам, поэтому формы ее реализации должны быть привлекательными для студентов.

Итак, в рамках внеурочной деятельности в колледже Московского гуманитарного университета 27 октября 2016 г. была реализована учебная экскурсия. Автобусная учебная экскурсия в подмосковный город-музей Коломну была подготовлена и, в основном, осуществлена студентами третьего курса специальности «Туризм». Поэтому данное мероприятие мы определяем как учебную экскурсию и своего рода деловую ролевую игру, так как перед студентами стояла задача практического применения сформированных общих профессиональных компетенций.

Подобные мероприятия проводятся нами в течение последних двух лет, поэтому можно говорить об определенном опыте и возможности развития этого направления. Такое внеаудиторное мероприятие позволяет отработать и конкретизировать многие профессиональные и общие компетенции в рамках изучения МДК.02.01 - Технология и организация сопровождения туристов, МДК.02.02 - Организация досуга туристов и МДК.02.03 - Организация экскурсионных услуг.

Перед поездкой нами была проведена большая подготовительная работа, распределены роли: сопровождающего, экскурсоводов, экскурсантов, аниматоров. Разумеется, что-то было осуществлено довольно условно, что-то более профессионально. Но главное - мы избежали той распространенной профанации, когда студенты воспринимают экскурсию как своеобразную веселую тусовку с неизбежным навязчивым и надоедливым вмешательством взрослых. Этого в нашем варианте быть не могло, ибо здесь и «актерами», и «зрителями» были сами студенты.

Особенности деловой игры как средства моделирования разнообразных условий профессиональной деятельности, имитации рабочего про- 
цесса, моделирования, упрощенного воспроизведения реальной производственной ситуации на сегодняшний день справедливо считаются методами интерактивного обучения, поскольку снимают противоречия между абстрактным характером учебного предмета и реальным характером профессиональной деятельности.

Учебная экскурсия, по нашему мнению, в этом отношении представляет собой благодатный материал. При выборе места проведения данной экскурсии руководствовались тем, что в Коломне прекрасно сохранился исторический центр города, а также разработана одна из лучших современных анимационных музейных программ в «Музее-фабрике Пастилы».

В проблемной лекции заранее перед участниками были поставлены задачи, озвучена программа, коротко, но ярко обозначены ключевые моменты предстоящего путешествия и его объектов. Затем все участники получили свои темы, задания и роли.

Перед поездкой мы обсудили ключевые моменты истории Коломны и ее главные экскурсионные объекты. Были обозначены здания и для тех, кто выступал просто в роли экскурсантов, поскольку одной из главных задач внеурочного мероприятия было активизировать всех участников, пробудить в них творческие силы, создать атмосферу доброжелательности и доверия, с одной стороны, соперничества и творческой дискуссии с другой.

Как уже было сказано, участники поездки выполняли индивидуальные и отчасти командные роли. При этом все действующие лица, включая преподавателей, находились в среде, представляющей профессиональный контекст имитируемой в игре деятельности специалистов.

Мы считаем, что современные студенты во многом подготовлены к подобной реализации учебного процесса, с большим удовольствием выполняют порученные роли и с большой долей ответственности. Отчасти это объясняется фактом активного участия современной молодежи в настольных и живых ролевых играх.

Напомним, что ролевая игра - это мероприятие обучающего или развлекательного назначения, участники которого действуют в рамках выбранных ими ролей, вместе они создают или следуют уже созданному сюжету. Ныне активно формируется представление о ролевой игре не только как о форме проведения досуга, но и об одном из методов воспитания, обучения.

Тем более, когда само реальное пространство ее осуществления обустроено с такой любовью и пониманием исторического контекста, как это делается в Коломне. Отметим большую организованность и заинтересованность всех участников поездки. На конкретных примерах было понимание процесса изучения маршрута и предлагаемых на нем услуг, особенности некоторых профессиональных компетенций и обязанно- 
стей, достойного воплощения анимационной программы - причем не в отвлеченной теоретической форме, а путем самостоятельного живого участия. Ныне ролевые игры часто становятся интересной основой исторической анимации, что и было изучено студентами на прекрасном, возможно, лучшем на сегодняшний день примере в Музее-фабрике пастилы города Коломна. Мы считаем, что у подобной анимации, как и вообще ролевых игр, большое будущее в плане использования в учебном процессе, его глубоком переживании, а не только механическом запоминании. Термин анимация (от лат. animation - оживлять, воодушевлять, одухотворять) впервые появился в начале XX века во Франции и трактовался как деятельность, направленная на то, чтобы провоцировать и усиливать живой интерес к культуре, художественному творчеству (Асанова, 2011).

Ныне туристская анимация представляет собой услугу, при оказании которой турист вовлекается в активное действие.

В сегодняшнем экскурсионно-познавательном туризме познание и анимация тесно связаны между собой, одно без другого практически немыслимо. Коломна в данном отношении является успешным и показательным городом.

Музейная фабрика пастилы в Коломне - первый в российской практике опыт живой реконструкции с элементами театрализации и анимации и самостоятельной активности посетителей, ее программа выполнена в музейной практике реально прожитой жизни.

Непосредственно участвуя в театрализованной программе, студентам удалось «попасть» в начало XX века, познакомиться с бытом богатого русского купечества и началом российской промышленности. Анимационная программа проходила в очень активной форме: своими руками наши студенты взбивали, протирали и стелили пастилу, знакомились с принципом работы первых кондитерских механизмов.

Факт непосредственного участия, а также мастерски используемое музейное пространство произвели огромное впечатление на студентов. Они по достоинству оценили возможности игровой гастрономической анимации, умение создать позитивное настроение у туристов и непринужденную, развлекательную и экскурсионную манеру общения.

С удовольствием отметим, что студенты не только участвовали в музейной анимационной программе, но на основе пройденного на аудиторных занятиях материала предприняли попытку на основе истории Коломны, ее географических и топографических возможностей предложить свои анимационные программы. Это было непросто, учитывая необыкновенно успешную активность местных предпринимателей турбизнеса. И, тем не менее, это удалось. В период формирования анимационной программы студенты обращали главное внимание на целевую 
аудиторию, главную идею программы, построение анимационного события и пути для достижения цели. Правда, задания были выполнены в виртуальной форме. Но мы считаем, что при наличии финансовых средств они вполне могут быть воплощены, причем успешно.

Сегодня, как и в древности, город стоит на перекрестке трех крупных рек, некогда крупных торговых водных путей - «из варяг в греки».

Основываясь на этом, студенты предложили создать на основе исторической реконструкции туристическую ладью для небольшого водного путешествия вдоль берегов древней Коломны в весенне-летний период. Они самостоятельно выбрали место для пристани, маршрут водного путешествия и даже точку для представления аудитории этой анимационной программы путем зрительной реконструкции. Поскольку на протяжении ряда столетий Коломна была крупным купеческим городом, студенты предложили и соответствующую анимационно-досуговую программу, которая бы создавала характерный тип горожанина с традиционным (особенно для русского купечества) чаепитием. Студенты предложили также на одной из главных улиц коломенского Кремля создать такой небольшой анимационно-развлекательный комплекс под названием «Коломенское чаепитие» с интерьером, оформленном в соответствующем стиле и даже костюмированными экскурсоводами - своеобразную экскурсионно-театрализованную программу.

Студентами предложена третья анимационная программа, обыгрывающая славу знаменитого коломенского горшка - создать музей-мастерскую «Гончарный двор» с такими преимуществами, как наглядность, возможность проведения мастер-классов с самостоятельным производством неповторимых сувениров.

Учебная экскурсия завершилась уже необходимым в таком эксперименте анализом и подведением итогов. Это выразилось не только во всестороннем коллективном обсуждении результатов экскурсии уже в аудитории, но в виде задания по составлению Отзыва сопровождающего о проведенной экскурсии (предусмотрено учебным планом по дисциплине «Технология и организация сопровождения туристов»).

Мы считаем, что это прекрасная форма стимулирования творческой активности участников, позволяющая отработать многие профессиональные навыки. В результате с большой долей успешности были достигнуты следующие цели:

- формирование познавательных и профессиональных мотивов и интересов; воспитание системного мышления участников;

- передача целостного представления о профессиональной деятельности и ее крупных фрагментах с учётом эмоционально-личностного восприятия; 
- обучение коллективной мыслительной и практической работе,

- формирование умений и навыков социального взаимодействия и общения, навыков индивидуального и совместного принятия решений;

- воспитания ответственного отношения к делу, уважения к социальным ценностям и установкам коллектива и общества в целом;

Кроме того, подобное внеурочное мероприятие позволило оценить:

- уровень владения вышеуказанными навыками;

- особенности мыслительных процессов (стратегическое, тактическое, аналитическое мышление, умение прогнозировать ситуацию, умение принимать решения и пр.);

- уровень коммуникативных навыков;

- личностные качества участников.

Отметим как немаловажную деталь: подобное выездное внеаудиторное мероприятие позволяет формировать дружеские и одновременно творческие, рабочие взаимоотношения среди участников, обеспечить взаимопонимание внутри коллектива, формировать общую культуру поведения, повышать познавательную активность студентов (Попова, 2013).

Таким образом, данная форма обучения способствует формированию целого комплекса общих компетенций у студентов - общекультурной, учебно-познавательной, информационной, коммуникативной.

Огромным преимуществом данного внеурочного мероприятия явилось то, что учащимся удалось охватить в одной учебной экскурсии сразу несколько видов деятельности, а именно: сопровождение, экскурсоведение, анимацию.

Студенты научились выступать перед аудиторией, отвечать на вопросы, находить выход из конфликтных ситуаций. Созданная атмосфера дисциплинирует студентов, учит хорошим манерам и ведению делового конструктивного диалога. Предлагаемая форма проведения внеурочных мероприятий, как показывают наблюдения и опрос студентов, всегда позитивно воспринимается обучающимися, активизирует их познавательный процесс, привлекает к практической деятельности.

Студенты проявили большую заинтересованность и готовы участвовать в разработке тематики будущих экскурсий и поездок, что свидетельствует об успешном профессиональном становлении будущих специалистов. Они готовы к более сложным целям, связанным с необходимостью выработки новых средств работы, саморазвития, развития организации. Собственно, работа над формированием таких целей - одна из главных задач инновационной деловой ролевой игры.

Анализ проведенной работы показал, что чередование внеучебной работы с теоретическими знаниями, позволяет достичь высоких результатов при освоении основной профессиональной образовательной про- 
граммы в соответствии с федеральным государственным образовательным стандартом, обеспечивает более эффективную самостоятельную работу студентов, что в конечном итоге способствует формированию общих и профессиональных компетенций, усиливает интерес к осваиваемой специальности, повышает мотивацию к обучению.

\section{СПИСОК ЛИТЕРАТУРЫ}

Асанова, И. М. (2011) Организация культурно-досуговой деятельности: учебник для студ. учреждений высш. проф. Образования. М. : Издательский центр «Академия». 192 с.

Емельянов, Б. В. (2007) Экскурсоведение. М. : Советский спорт. 216 с.

Попова И. Н. (2013) Организация внеурочной деятельности в условиях реализации ФГОС // Народное образование. № 1. С. 219-226.

Дата поступления: 01.12.2017 г.

Воронина Алла Валентиновна - преподаватель колледжа Московского гуманитарного университета. Адрес: 111395, Россия, г. Москва, ул. Юности, д. 5, корп. 11. Тел.: +7 (499) 374-68-09. Эл. адрес: voronina. gid@mail.ru

Марянян Мария Сергеевна - преподаватель колледжа Московского гуманитарного университета. Адрес: 111395, Россия, г. Москва, ул. Юности, д. 5, корп. 11. Тел.: +7 (499) 374-68-09. Эл. адрес: maryanyan.mari@ yandex.ru

Voronina Alla Valentinovna, Teacher, College, Moscow University for the Humanities. Postal address: 5, Bldg. 11, Yunosti St., Moscow, Russian Federation 111395. Te.: +7 (499) 374-68-09. E-mail: voronina.gid@mail.ru

Maryanyan Maria Sergeyevna, Teacher, College, Moscow University for the Humanities. Postal address: 5, Bldg. 11, Yunosti St., Moscow, Russian Federation 111395. Te.: +7 (499) 374-68-09. E-mail: maryanyan.mari@yandex.ru

\section{Для циитирования:}

Воронина А. В., Маранян М. С. Учебная экскурсия как современная форма интерактивного занятия [Электронный ресурс] // Научные труды Московского гуманитарного университета. 2017. № 6. URL: http://journals.mosgu.ru/trudy/article/view/620 (дата обращения: дд.мм.гг.). DOI: 10.17805/trudy.2017.6.4 